\title{
THE URINARY EXCRETION OF ANDROGENIC AND ESTROGENIC SUBSTANCES IN CERTAIN ENDOCRINE STATES. STUDIES IN HYPOGONADISM, GYNECOMASTIA AND VIRILISM ${ }^{1}$
}

\author{
By A. T. KENYON, T. F. GALLAGHER, D. H. PETERSON, R. I. DORFMAN AND \\ F. C. $\mathrm{KOCH}$ \\ (From the Departments of Medicine and Biochemistry of the University of Chicago, Chicago)
}

(Received for publication March 15, 1937)

The comparison of the excretion of male and female hormone-like substances with the clinical expressions of disease may be expected to teach us the extent to which studies of the urine reveal the changing functions of the gonads and may help to illuminate the difficult pathological physiology of such obscure processes as virilism and gynecomastia. As a step in this direction we are presenting data on castration in the male, eunuchoidism, hypopituitarism, bilateral cryptorchidism without alteration in secondary sex characters, gynecomastia, precocious puberty and virilism.

The assays were conducted according to the technique of Gallagher, Koch and Dorfman (1) as outlined in the preceding paper dealing with the normal (2). In all cases complete urine collections were secured through a number of days. During the bulk of the work the acidified urine was boiled for two hours to insure the maximum yield of estrogenic material. When it was learned that briefer boiling gives measurably higher values for male hormone than either boiling for two hours or none at all, this procedure was introduced in a few instances. The urine was then extracted with benzene in a continuous extractor, the benzene distilled off and the residue distributed between ether and 10 per cent aqueous sodium hydroxide. Ninety-five per cent of the estrogenic material passes into the alkali and none of the androgenic. The androgenic fraction was assayed on from four to seven capons according to the technique of Gallagher and Koch (3) and the estrogenic fraction on ten spayed adult female rats, according to the vaginal spread technique of D'Amour and Gustavson (4). As emphasized in the preceding paper, rigid comparisons were always made with standard preparations to permit control of the inevitable variations in the animal

\footnotetext{
1 These investigations were supported in part by a grant from the Rockefeller Foundation.
}

colonies and the environment. The values for male hormone are expressed in the newly adopted international unit, each unit representing the activity equivalent to that of $0.1 \mathrm{mgm}$. of androsterone. The values for estrogenic material are expressed in $\gamma$ of theelin $(0.001 \mathrm{mgm}$. or 10 international estrogenic units).

It must not be supposed that our assays estimate single pure substances. Both androsterone and dehydroandrosterone have been shown to be constituents of the comb-growth stimulating mixture in urine, and both theelin (oestrone) and theelol (oestriol) are probably present. Quite possibly some of the many known relatives of these may in time be identified in urine. The suggestion of Deanesly and Parkes (5) that some of the estrogenic activity in male urine is due to dehydroandrosterone is not applicable to our data because this substance will not pass into the alkaline fraction on which the female assays are made. No attempts have been made in our studies to determine separately the estrogenic activity extractable from fresh urine and that larger amount extractable from hydrolyzed urine although useful information may well be secured in this way, as in Cohen and Marrian's studies of pregnancy. Our observations are of "total estrogens."

\section{HYPOGONADISM IN THE MALE}

\section{A. Castration}

The castrated individual provides the proper base line for all studies on the excretion of sex hormones. In the absence of the gonads the continued presence of such material in the urine must be attributed either to some other organ or to the food. McCullagh and Renshaw (6) found no comb-growth promoting material in the chloroform extracts of the urine of eleven eunuchs. Of these, seven were 50 years of age or more, an age group in which it has been claimed but not sub- 
TABLE I

The excretion of sex hormones in hypogonadism in the male

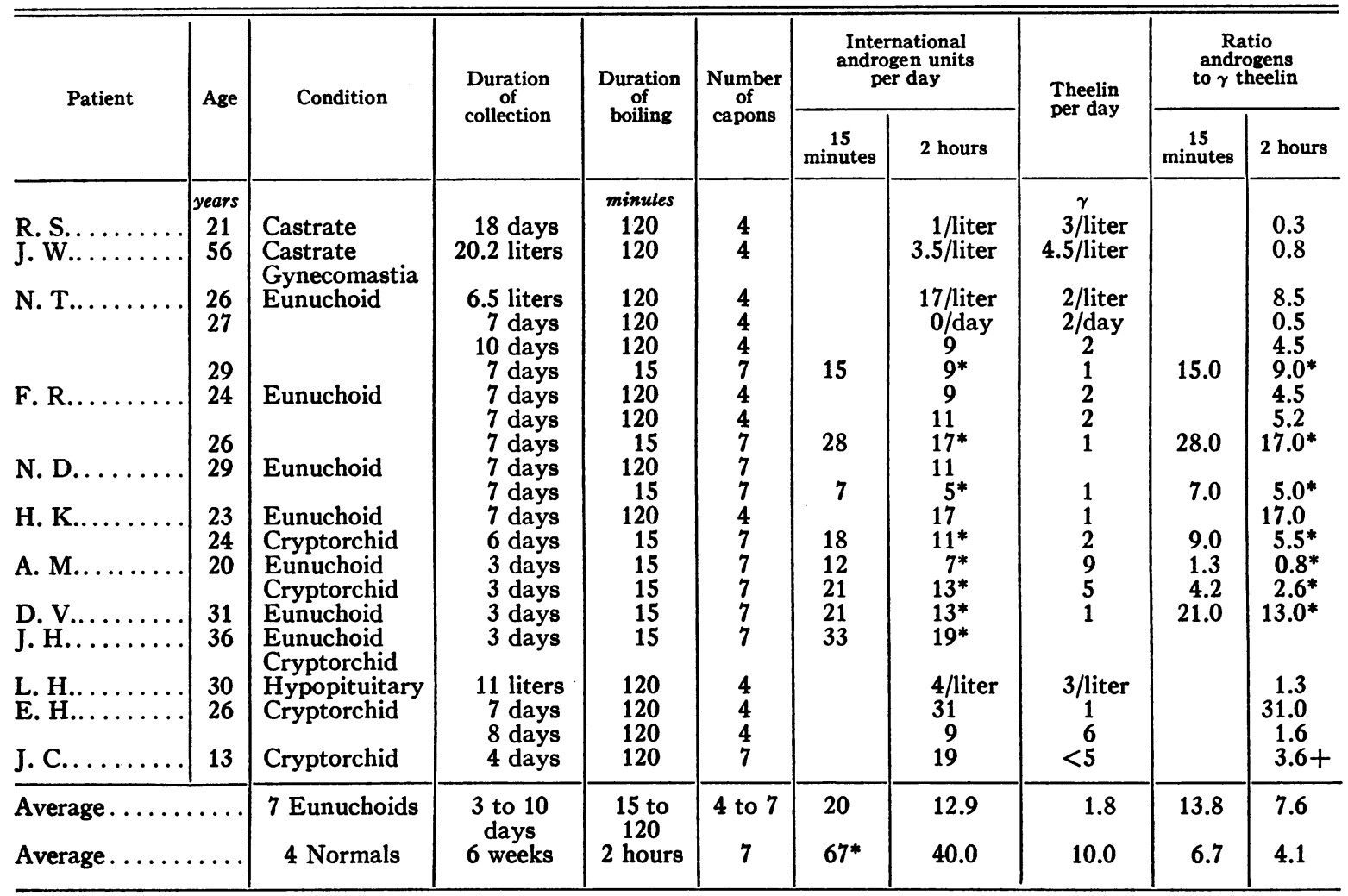

* Calculated on the assumption that the 2-hour hydrolysis gives values 60 per cent of those secured by the 15 -minute hydrolysis. This relationship may also be expressed by the statement that the 15 -minute hydrolysis gives values 66 per cent above that of the 2-hour hydrolysis.

stantiated that the male hormone excretion is normally diminished. Eng ( 7 ) found 2 to 15 mouse units per liter of estrogenic material in the urine of three castrated women and 2 to 17 mouse units per liter in the urine of four castrated men. Five to 15 mouse units per day were excreted in the feces of the eunuchs. In one patient, nine days on a "folliculin"-free diet caused no decline in the excretion of estrogenic material which Eng therefore felt was of endogenous origin. Frank, Goldberger and Salmon (8) found that the urine of twelve women castrated surgically and 3 castrated by $\mathrm{x}$-ray contained from 15 to 200 mouse units of estrogenic substances per liter. In two cases, 255 and 720 mouse units were excreted per month as compared to 1,500 in the normal. Dingemanse, Borchardt and Laqueur (32) have recently reported 6 to 12 international androgen units per liter in the urine of three oophorectomized women.
We have been able to examine the urine of two castrated men. Unfortunately, neither case is beyond criticism, as one was 56 , belonging to an insufficiently understood age group and the other had schizophrenia which may itself have had some influence. Furthermore, in the former, confirmation of the surgical procedure is now impossible and the gynecomastia present raises doubts concerning the completeness of the castration.

R. S. (Referred by Dr. J. M. Austin), negro, age 21. The patient, severely affected with dementia praecox of catatonic type, had been completely castrated by a fellow patient at the South Carolina State Hospital, Columbia, South Carolina, in January 1934. Practically the entire penis had been removed in the mutilation. The urine was collected with great difficulty through the generous efforts of Dr. James M. Austin, by an inlying catheter during eighteen of twenty-one days in December 1934. No physical consequence of the castration had been noted in twelve months.

J. W. (Referred by Dr. O. W. Thompson), negro, 
age 56. The patient was obese and effeminate and had large breasts. At the age of 19 he had supposedly been castrated because of infection following a bilateral operation for undescended testicles. A complete collection of urine amounting to 20.2 liters was secured.

Traces only of androgenic and estrogenic material were present in the urine (Table I). This is in accord with the view that the bulk of the hormone-like constituents of male urine are of gonadal origin and suggests that traces may come from elsewhere. These studies, however, must be extended as suitable material presents itself.

\section{B. Eunuchoidism-Hypopituitarism}

Seven men studied represent that form of hypogonadism known as eunuchoidism since the early descriptions of Tandler and Grosz (31). While commonly recognized, the syndrome has received little attention in the American literature. It is characterized by hypoplasia of the genitalia and their accessories with impairment of the mechanism of ejaculation, retardation in development of the secondary sex characters, delay in closure of the epiphyses of the long bones, and absence of obvious constitutional disturbance. While presumably a wide variety of agents injuring the testes or the pituitary body may cause the syndrome, one usually cannot find clear indications of them. If defect in the pituitary is responsible, the gonadotropic properties must alone be involved. The most detailed pathological study available, that of Altmann (9), certainly has disclosed no considerable pituitary lesion, and the variety and inconsistency of the microscopic findings leaves one much in the air as to the rôle of this organ. Such attempts as we and others (10, 11) have made to find excessive prolan in the urine have failed, but we hesitate to make too much of this as proof of primary responsibility of the hypophysis.

No studies have been made to our knowledge of the excretion of male and female hormones in this syndrome. A more detailed clinical study of these people will be reported subsequently.

N. T. (Referred by Dr. I. Becker) (University of Chicago Clinics number 87890), age 26. The patient was of normal height and weight with scant pubic and axillary hair, and only a slight fuzz on the upper lip. The laryngeal prominence was absent and the voice boy- ish. The testes were small, measuring $2.7 \times 1.7 \times 1.3$ $\mathrm{cm}$., the epididymides small and the rudimentary prostate, barely detectable when first examined, was, two years later (January 1936), well defined but still very small. The penis was $4.7 \mathrm{~cm}$. long. Erections occurred occasionally and small ejaculates of albuminous material have been procurable since August 1935. Creatinuria was demonstrable. Basal metabolism, glucose tolerance, visual fields, and $\mathrm{x}$-rays of the sella turcica were normal. Numerous epiphyseal lines were open from three to five years beyond the slowest normal. The urine as reported by Dr. Z. Wallen-Lawrence did not contain the large amount of gonadotropic material present in that of many castrates.

Assays were performed on a composite specimen of 6,500 cc. collected between January 24 and May 1, 1934, on a 7-day specimen between September 5 and 12, 1934, on a complete 10-day specimen between October 6 and 15 , 1934, and on a complete 7-day collection ending January $7,1936$.

F. R. (University of Chicago Clinics number 113589), age 24. Of normal height and weight with deficient axillary and pubic hair and a smooth face, the patient had a history both of serious head injury and of a dermatitis involving the scrotum. The laryngeal prominence was absent, and the voice somewhat high in pitch. The testes measured $2.2 \times 1.4 \times 1.1 \mathrm{~cm}$., the epididymides were small and the prostate just apparent. The penis was $4.7 \mathrm{~cm}$. long. Erections occurred occasionally, ejaculates never. Creatinuria was demonstrable. Basal metabolism, glucose tolerance, visual fields, and $\mathrm{x}$-rays of the sella turcica were normal. Numerous epiphyseal lines were unfused two to six years beyond the slowest normal. The urine did not contain the large amount of gonadotropic material present in that of many castrates.

Two complete 7-day collections in November 1934 and one complete 7-day collection ending January 7, 1936, were assayed.

N. D. (Referred by Dr. M. Kolovros) (University of Chicago Clinics number 134245), age 29. The patient was very thin and of normal height with scant pubic and axillary hair and a smooth face. The laryngeal prominence was absent, and the voice was somewhat high in pitch. The testes measured $2.2 \times 1.5 \times 1.4 \mathrm{~cm}$., the epididymides were small, and the prostate practically imperceptible. The penis was $4.2 \mathrm{~cm}$. long. Erections occurred but no ejaculations. Creatinuria has been observed. Basal metabolism, glucose tolerance, visual fields and $\mathrm{x}$-rays of the sella turcica showed nothing unusual. Various epiphyseal lines were unfused from four to nine years beyond the slowest normal. His arms and legs were disproportionately long. The urine did not contain the large amount of gonadotropic material present in that of the castrate.

Complete 7-day urine samples during August 1935 and January 1936 were examined.

H. K. (University of Chicago Clinics number 121217), age 23. The patient was of normal height and somewhat 
heavy, with little pubic and axillary hair and a smooth face. The laryngeal prominence was not present, but the voice was normal. The testes were not present and expert surgical intervention disclosed them too high to be effectually drawn down. The prostate could not be felt. The penis was $3.5 \mathrm{~cm}$. long. Erections occurred but no ejaculations. Glucose tolerance showed a curve of mild diabetes; basal metabolism, visual fields and $\mathrm{x}$-rays of the sella turcica were normal. There was evidence of delay in epiphyseal fusion of as much as five years.

A 7-day collection during August 1935, and a 6-day collection during May 1936, were assayed.

A. M. (Referred by Dr. Henry Schmitz) (University of Chicago Clinics number 152001), age 20. The patient was of normal height but quite obese with scant axillary and pubic hair and a small amount of terminal hair on the upper lip which had remained as at present for five years. The laryngeal prominence was slight and the voice boyish. The testes could not be felt, nor could the prostate. The penis was $3.5 \mathrm{~cm}$. long. Erections but no ejaculates occurred. Basal metabolism, glucose tolerance, visual fields and $\mathrm{x}$-rays of the sella turcica were normal. There was little significant delay in epiphyseal fusion.

Two 3-day collections in June 1936 were assayed.

D. V. (Referred by Dr. Paul Bucy) (University of Chicago Clinics number 41111), age 31. The patient was of normal height and weight with a small amount of axillary and pubic hair and smooth upper lip. A small laryngeal prominence was apparent and his voice approached normal. The testes measured $3.5 \times 2.0 \times 1.7$ $\mathrm{cm}$., the prostate was small but definite. The penis varied from 3.8 to $6.2 \mathrm{~cm}$. long. Erections but no ejaculations occurred. Basal metabolism, glucose tolerance and $\mathrm{x}$-rays of the sella turcica were normal. Bilateral optic atrophy of moderate grade had been present for years, and had not progressed. The fusion of several epiphyses was delayed seven to eight years.

A 3-day collection in July 1936 was assayed.

J. H. (Referred by Drs. Carl Moore and C. B. Huggins) (University of Chicago Clinics number 160510), age 36. The patient was of normal height and weight with a small amount of axillary and pubic hair and only a little fine fuzz on the upper lip. The laryngeal prominence was small, and his voice was normal. Neither testis was palpable. The penis was $4.1 \mathrm{~cm}$. long. Erections but no ejaculations occurred. Basal metabolism, glucose tolerance, visual fields and sella turcica roentgenogram were normal. Several unfused epiphyseal lines were present.

A 3-day collection in October 1936 was assayed.

We have also been able to examine the urine of one patient in which the hypogonadism was proved to be due to a chromophobe tumor of the pituitary body.

L. H. (Referred by Drs. Percival Bailey and Paul Bucy) (University of Chicago Clinics number 87850), age 30 . The patient suffered from weakness, decline in vision, loss of body hair and impotence. There was a globular enlargement of the sella turcica, with a depression of its floor on $x$-ray. Visual fields showed a right temporal hemianopsia. His basal metabolism was -40 per cent and below on several occasions and his blood pressure was not infrequently as low as 86/54. X-ray therapy to the pituitary region had been given before the urine collection was made. He has since shown improvement in his general condition, his vision has not further declined, but he is still impotent.

A complete 11-liter urine collection was made in May 1934 and assayed.

Table I presents the data on these instances of hypogonadism. It will be recalled from the preceding paper that the four normal young men studied continuously for six weeks averaged in the neighborhood of 40 international androgen units of male hormone per day each, with a range of 13 to 79, seven capons being used for each assay and the urine being boiled for two hours before extraction. If we allow for the destruction of 40 per cent of the androgenic material between the 15 minute hydrolysis and the two hour hydrolysis, as described in the preceding paper, this average normal value becomes 67 international units per day, and the range 22 to 132 . In contrast with this the seven-capon assays on the seven eunuchoids give an average value of 20 units of male hormone, with a range of 7 to 33 , by the 15 minute hydrolysis. The four capon assays with the two hour boiling on the eunuchoids give good corroboration. It should be noted that there is some overlapping of the normal and the hypogonad. This is not surprising when we recall that all of our eunuchoids have developed such secondary sex characters as axillary and pubic hair to the extent reached by the fourteen or fifteen year old boy, and thus present some clinical evidences of testicular activity. On the average, our hypogonads excrete about a third of the normal amount of male hormone.

With the exception of one assay on Patient A. M. the excretion of estrogenic material is reduced to traces in the eunuchoid, and while this level is reached on occasion by the normal, the average normal value is $10 \gamma$ per day. The values for both male and female hormones in the patient with hypopituitarism (L. H.) are low. 


\section{Cryptorchidism without alteration in sec- ondary sex characters}

Our data on this point are scant. It is of interest that Patient E. H., who had well-developed secondary sex characters, reached well into the normal range on one of two assays for androgenic material. The other patient, J. C., is 13 and while there are some signs of puberty, it will be several years before the degree of retardation in the development of secondary sex characters can be accurately judged (Table I).

E. H. (Referred by Dr.W.M. Brunet) (University of Chicago Clinics number 118497), age 26. The patient was bilaterally cryptorchid, the left testis being in the inguinal canal and the right probably at the ring, where some testicular sensation could be secured by pressure. His ejaculate contained no sperm but his genitalia and secondary sex characters were well developed.

Complete urine collections for one 7-day and one 8-day period were made in January 1935.

J. C. (Referred by Dr. H. T. Ricketts) (University of Chicago Clinics number 137064), age 13. The patient was obese with impalpable testes, showed some pubic hair and a small well-defined prostate. Roentgenogram of the sella turcica showed no pathology. His basal metabolic rate was -28 .

Two 48-hour urine specimens were obtained in September 1935.

\section{PRECOCIOUS PUBERTY}

We have been able, through the efforts of $\mathrm{Dr}$. Thomas Myers of St. Paul, to examine the urine of one patient, a boy of five, with precocious puberty of unknown etiology. Unhappily, we could

TABLE II

The excretion of sex hormones in gynecomastia and precocious puberty

\begin{tabular}{|c|c|c|c|c|c|c|c|c|}
\hline Patient & Age & Condition & $\begin{array}{c}\text { Dura- } \\
\text { tion } \\
\text { of } \\
\text { colleo } \\
\text { tion }\end{array}$ & $\begin{array}{c}\text { Dura- } \\
\text { tion } \\
\text { of } \\
\text { boiling }\end{array}$ & $\begin{array}{c}\text { Num- } \\
\text { ber } \\
\text { of } \\
\text { capons }\end{array}$ & $\begin{array}{c}\text { Inter- } \\
\text { national } \\
\text { androgen } \\
\text { units/day }\end{array}$ & $\begin{array}{l}\text { The- } \\
\text { elin } \\
\text { per } \\
\text { day }\end{array}$ & $\begin{array}{l}\text { Ratio } \\
\text { andro- } \\
\text { gens } \\
\text { to } \gamma \\
\text { theelin }\end{array}$ \\
\hline $\begin{array}{l}\text { K. } \mathbf{L} \ldots \ldots \\
\text { J. } \mathbf{B} \ldots \ldots \\
\text { T. W...... } \\
\text { Boy..... }\end{array}$ & $\begin{array}{c}\text { years } \\
16 \\
24 \\
15 \\
5\end{array}$ & $\begin{array}{c}\text { Gynecomastia } \\
\text { Gynecomastia } \\
\text { Gynecomastia } \\
\text { Precocious } \\
\text { puberty }\end{array}$ & $\begin{array}{c}\text { daye } \\
6 \\
\mathbf{3} \\
7 \\
7\end{array}$ & \begin{tabular}{|c|} 
hours \\
2 \\
2 \\
2 \\
2
\end{tabular} & $\begin{array}{l}7 \\
7 \\
6 \\
6\end{array}$ & $\begin{array}{r}37 \\
00 \\
8 \\
00\end{array}$ & $\begin{array}{r}\gamma \\
15 \\
12 \\
5\end{array}$ & $\begin{array}{l}2.5 \\
0.1- \\
1.6\end{array}$ \\
\hline
\end{tabular}

demonstrate no male hormone, a finding of which we are skeptical and which requires confirmation. It is conceivable that the high basal metabolism may have modified the results (Table II).

This boy, age 5, was $48 \frac{1}{2}$ inches tall, weighed 58 pounds and was strong and muscular. Pubic hair and rapid growth of the genitalia had been observed during the preceding year. His voice was bass, and acne had been present on his face for one and a half years. $\mathrm{X}$-rays of the carpus showed all eight bones present and well developed as at 12 . The skull was not definitely abnormal. Three basal metabolism tests showed +36 , +40 and +57 , but clinical signs of hyperthyroidism appeared to be absent. Mentally he was sound, and no evidences of unusual libido were present.

A complete urine collection for seven days was secured in the winter of 1935.

\section{GYNECOMASTIA}

The appearance of feminine breast tissue in men is rare and somewhat difficult to explain. Lewis and Geschickter (12), who have examined the tissues of ninety-five instances of gynecomastia, find consistently a proliferation of the ducts and periductile connective tissue, with no alveolus formation, a picture similar to that in virginal breast hypertrophy. As such a development has been produced by giving estrin to male monkeys and is in accord with the widely known effects of estrin in other species (13), it is most natural to suppose this feminizing material to be the active agent. Testosterone benzoate, however, was also shown to stimulate the tubuloacinar system of the breast of the rat to some extent (14), and androstane-diol, a synthetic relative of the male hormone, not appearing as far as is known in the animal body, has a powerful mammotropic effect in the rat (15). Unexpected difficulties with the theory of hyperfunction of the testis, the presumable source of either the estrogenic substances or testosterone, are encountered, however, when the clinical associations of gynecomastia are reviewed, for testicular atrophy is common (16). While such secondary sex characters as hairgrowth may be deficient they are usually normal in these people. Whether interstitial cell hypertrophy, which is known to accompany testicular atrophy frequently, will be found often enough to provide a source for the active agent, is still uncertain. When chorioepithelioma produces gynecomastia, the proliferating decidua-like tissue may readily be conceived a source of augmented estrin secretion, but even here we cannot be too casual. Hamburger (10) in a most careful study found gynecomastia when the amount of gonadotropic material in the urine was the least and in a patient in which the second testis had been destroyed. 
The data on the excretion of hormones in gynecomastia is scant. Heidrich, Fels and Mathias (17) found 250 mouse units per liter in a man with teratoma of the testicle. Hamburger (10) detected estrogenic activity in the urine of one such patient and not in that of another.

We have been able to examine the urine of four patients with bilateral gynecomastia. One, a young boy, in whom the enlargement did not greatly exceed that which Jung and Shafton (18) have shown to be common in adolescent boys, also had a mild hyperthyroidism which may well have accentuated the process (19). One patient had hypoplasia of the testes, one an enlarged painful testicle following mumps orchitis, and one, a cryptorchid (J. W., summarized as a castrate), had been subjected, supposedly, to a bilateral orchidectomy.

K. L. (Referred by Dr. W. S. Timblin and Dr. C. B. Huggins) (University of Chicago Clinics number 133404), age 16. For six months the patient had had enlargement of the breasts comparable to that of many adolescent girls. His penis and prostate were normal, axillary and pubic hair abundant, facial hair normal for his age, his voice adult. The testes were small, measuring $2.5 \times 1.3 \times 1.2 \mathrm{~cm}$.

In the spring of 1936 a complete 6-day urine collection was secured.

J. B. (Referred by Dr.W. O. Thompson), negro, age 24. The patient had mumps orchitis eight years previously and had for seven years recurrent swelling and tenderness of the right testis. Biopsy showed normal testicular tissue. Enlarged painful breasts from which a white discharge could be expressed had been present for one year. He shaved a small circumoral beard twice weekly.

In March 1935 a complete 3-day urine collection was secured.

T. W. (Referred by Dr. H. T. Ricketts) (University of Chicago Clinics number 116057), age 15. The patient had breast enlargement for one year, the sub-areolar discs measuring 3 to $4 \mathrm{~cm}$. in diameter. The pubic and axillary hair and the genitalia were normal. There were signs of a mild hyperthyroidism (basal metabolic rate, $+18,+19)$ which subsided under iodine. Nine months later his breasts were smaller. A complete 3-day collection was secured in March 1935.

The data is presented in Table II. We have found no unusual amount of estrogenic material in the urine in any of our four patients (including J. W., the castrate) and hence are unable to bring support to the theory that gynecomastia is due to hyperestrinism. For two reasons, however, such negative results are not to be considered conclusive. First, samplings of a few days only form a highly imperfect representation of a process that evolves over months and years, and secondly, artificial and hence probably physiological additions of estrogenic material to the organism evoke a notoriously limited urinary excretion. The problem, of course, requires more extensive study. The excretion of androgens was variable.

\section{VIRILISM}

Virilism has a confusing variety of pathological associations among which no common denominator is as yet apparent. We may distinguish those instances accompanied by $(a)$ ovarian tumors, (b) adrenal tumors, (c) adrenal hyperplasia, $(d)$ pituitary tumors. In certain instances, the adrenal hyperplasia is accompanied by tumors of the anterior lobe of the pituitary body or carcinoma of the thymus. Cushing's theory (20) that basophile tumors of the pituitary body are often responsible for the hypertrophy of the adrenal cortex and the virilism is now well known, much discussed, and still subject to discussion. Crooke (21) has recently found hyaline changes consistently in the basophiles of the anterior lobe in a series of patients with and without adrenal or pituitary tumor, but presenting hypertrichosis, obesity of the face and trunk, hypertension and amenorrhea, thus giving the term "pituitary basophilism" an entirely different significance from that given it by Cushing. So great is the present confusion that the term Cushing's syndrome should be withheld unless an unequivocal pituitary tumor is found since a strictly clinical distinction between his patients and the long known suprarenal virilism has neither been claimed nor shown.

To these four groups must be added a fifth of undetermined pathology comprising by far the majority of those seen. These individuals suffer from hypertrichosis, together on occasion with hypertrophy of the clitoris and often with such substantial disturbances of the menstrual function as oligomenorrhea, amenorrhea and even menorrhagia. Obesity may occur but hypertension and asthenia are rare. The ovaries may be enlarged, sometimes cystic, sometimes fibrotic, the capsules much thickened, changes by no means specific. The adrenals are normal as far as manual ex- 
ploration can tell us. Adrenal hyperplasia (22) or occult pituitary or ovarian changes $(21,23)$ may be present, of course, but the necessary detailed autopsy studies are insufficient to permit full analysis of the problem.

A beginning has been made in the measurement of hormone excretion in virilism. Bühler (24) in 1933 reported 6 to 7 units of comb-growthstimulating material per day in the urine of a 28 year old girl with hypertrichosis, deep voice, large clitoris, and amenorrhea, by a method which yielded 1 to 2 units per day in normal men. Thirty-five to 40 mouse units of estrogenic material were found. Frank (25) in 1934 reported that in two patients with carcinoma of the suprarenal cortex he had found enormous quantities of estrogenic material in the urine. In the first patient, he records from less than 1,000 to 17,000 mouse units in three-day periods, a total of 57,000 mouse units during a time equivalent to a menstrual cycle. In the second patient, he found 5,000 units per liter. In upwards of 10 more patients without carcinoma, in one of which adrenal cortical hyperplasia was found at operation, he could find no excess. Kurzrok et al. (26) on the other hand, could find but 8 rat units per liter in their case Number 3, a proved carcinoma of the suprarenal cortex, the male-hormone assays on which we are reporting here. Similar values were found in two other girls with hypertrichosis, one with adrenal hyperplasia demonstrable by perirenal air injections. Simpson, de Fremery and Macbeth (27) in 1936 reported their assays on the urine in 12 varied instances of hypertrichosis and included two others examined by Dingemanse. By the comb-growth method, five patients showed a marked excess of masculinizing substance and four a more moderate excess. In three cases their values reached from 200 to 500 capon units per day by a technique which gave from 10 to 50 in the normal female. Of especial interest is the finding of between 25 and 50 units per day in the urine of a four-year old pseudo-hermaphrodite. One of their patients with high values was proved to have a carcinoma of the suprarenal cortex. Korenchevsky found in the urine of one of these cases an increase in prostate stimulating power when tested on the rat. The amount of estrogenic ma- terial did to some extent parallel that of the masculinizing substances. The case of carcinoma of the suprarenal cortex showed, however, less than 600 mouse units per day, and the highest in any case was recorded as "less than 1,440 ."

Slot (28) has recently described a 49 year old woman with amenorrhea, hypertrichosis and hypertension in which Dingemanse found 2,200 international units of comb-growth stimulating material per liter with 100 international units $(10 \gamma)$ of estrogenic substance. Despite this great excess of male hormone in the urine the adrenal tumor removed contained no more than the livers of normal individuals which served as his control. Saphir and Parker (23) have described a 15 year old girl with hypertrichosis, obesity and amenorrhea who had nests of clear adrenal-like cells in a removed ovary and who excreted 5,000 mouse units of estrogenic substances per liter of urine.

We were able to examine the urine of $16 \mathrm{pa}-$ tients with virilism. They ranged from 13 to 36 years of age; all had striking hypertrichosis, three an enlarged clitoris, and two, hypertension. Excluding the two youngest patients, six had amenorrhea, five irregular menses, and one menorrhagia. Only in two instances was menstruation normal. While several were obese, the rapidly developing facial and trunk obesity, remarked by Cushing, was present in but two (P. R., C. F.) and one of these had purplish abdominal and iliac striae. Two patients had carcinoma of the adrenal cortex proved at operation (G. C., K. P.) ; two had adrenal tumors proved at autopsy (P. R., C. F.). In seven others, the adrenals were explored surgically and found not demonstrably abnormal. In eight patients without known adrenal lesions, the ovaries at operation were enlarged in six, and in four of these were recorded as cystic. In one patient not operated on, large cystic ovaries were found on pelvic examination. In no case did roentgenograms of the sella turcica show pathology. In five patients, complete urine collections were secured for three or four days; in the remainder for five to ten days. In eight instances, there was no cyclic menstrual bleeding at the time of the urine collection.

R. Y. (Referred by Dr. C. B. Huggins) (University of Chicago Clinics number 58994), age 18. The patient 
had a boyish figure, hypoplastic breasts, enlarged clitoris and facial, abdominal and limb hypertrichosis. Physical and laboratory examinations were otherwise negative. Scant, transient vaginal bleeding occurred once each at 14 and 17. In 1932, Dr. C. B. Huggins explored the pelvis and found enlarged cystic ovaries which showed on section many primary follicles and numerous cystic spaces.

A complete urine collection for seven days was secured in March 1935 during amenorrhea.

M. N. (Referred by Dr. A. A. Weinstein), age 21 . The patient had striking facial and abdominal hypertrichosis, normal breasts, blood pressure and pelvic organs. Extensive laboratory examinations were negative. Menses since the age of 14 had recurred every five to eight weeks and lasted five days. Laparotomy in July 1934 at the Vanderbilt University Hospital showed normal adrenals and ovaries.

A complete urine collection for seven days was made in September 1934, beginning ten days after the onset of the preceding menstrual period.

E. H. (Referred by Dr. W. O. Thompson), age 29. The patient was somewhat obese with hypertrichosis of the face, chest, abdomen and extremities. Physical, laboratory and pelvic examinations were negative. Since March 1934, when she missed a menstrual period, she has flowed every six weeks. Beginning in September 1934 she flowed continuously for eight weeks. Curettage was then negative.

A complete 3-day urine collection was secured in June 1935. Relation to the cycle was not known to us.

M. A. (Referred by Dr. W. O. Thompson), age 23. The patient had hypertrichosis and menorrhagia since the menarche at 19. At operation, both ovaries were one and one-half times the normal size, the capsules much thickened. An operative note states that "exploration revealed no other lesions of note."

A complete 3-day collection of urine during December 1935 was examined. The relation of this collection to the menstrual cycle is not known to us.

A. D. (Referred by Dr. Edmund Andrews) (University of Chicago Clinics number 149906), age 32. The patient had great obesity, hypertrichosis of the face, abdomen and extremities, and amenorrhea for 19 months. Her blood pressure was $120 / 90$ and laboratory examination was negative. At operation there was an inflamed periappendicular mass, normal adrenals and enlarged thickened ovaries which showed on section much increase in stroma and little or no follicular activity. Following resection of parts of the ovaries, she bled vaginally.

A complete urine collection for six days was secured before the exploration, during amenorrhea, in April 1936.

W. K. (Referred by Dr. Henry Jacobs) (University of Chicago Clinics number 135457), age 21. The patient was an obese girl, with hypertrichosis of the abdomen, extremities and face, hypoplastic breasts, and a deep masculine voice. Since the menarche at 21 , the menses have been very irregular. Physical, pelvic and laboratory examinations have added nothing further.

A complete urine collection for six and a half days was made just before a menstrual period in September 1935.

E. S. (University of Chicago Clinics number 60628), age 25. The patient was obese and had hypertrichosis of the face and abdomen, and amenorrhea, with a history of menorrhagia. Physical and laboratory examinations added nothing. Pelvic examination showed enlarged cystic ovaries. In June 1935, Dr. Virgil S. Counsellor operated on her at the Mayo Clinic and resected parts of the large cystic ovaries which on section were recorded as polycystic with oophoritis. The adrenals were not definitely abnormal. An x-ray treatment to the pituitary body was given. In July 1935, she returned to the University of Chicago Clinics (Dr. W. J. Dieckmann) with menorrhagia which subsided after curettage. Brief oneand-a-half-day periods have recurred monthly since.

A 10-day urine collection was secured in January 1935 during amenorrhea.

G. F. (Referred by Dr. W. O. Thompson), age 17. She had hypertrichosis of the face, chest, abdomen and extremities. Menses at first every two or three months have been regular recently since taking theelin. Physical and laboratory examinations are negative. At operation (Cook County Hospital) the ovaries were found to be the size of small lemons, "not very cystic" and contained one or more hard nodules which proved to be fibromata on microscopic examination. The ovarian stroma was in part normal and in part fibrotic with evidence of old and recent ovulation present. The adrenals were normal.

We have examined a complete urine collection amounting to five liters collected in March 1934. The time in the cycle is not known to us.

C. F. (Referred by Dr. Louis Leiter) (University of Chicago Clinics number 141740), age 31. The patient was obese with swelling especially about the face, with hypertrichosis of the face, abdomen and extremities. Her blood pressure ranged from $150 / 100$ to $220 / 120$. Her previously regular menses had stopped six months before. Pelvic examination was negative. There were no purplish striae, or polycythemia. Osteoporosis and ecchymoses on slight pressure were present. Basal metabolism and sella turcica $x$-rays were negative. The urea clearance showed good kidney function. Exploratory laparotomy (Dr. D. B. Phemister) in March 1936 revealed normal ovaries and adrenals.

Subsequently the patient's kidney function declined and she died on March 20,1937, with renal and myocardial failure. Autopsy by Dr. Eleanor Humphreys showed a small pigmented adenoma in the right suprarenal gland with venous thrombosis and focal necrosis; extreme simple atrophy of the left suprarenal gland and of the remainder of the right; focal atrophy and necrosis ( $x$-ray effect?) in the anterior lobe of the hypophysis with focal adenomatous hyperplasia, but without basophile adenoma or basophilic infiltration of the neurohypophysis. There 
was widespread atherosclerosis, especially of the small arteries and arterioles; arteriolosclerotic atrophy of the kidneys and pancreas; cardiac hypertrophy and dilatation with focal scarring and myomalacia and marked fatty degeneration; visceral chronic passive hyperemia, ascites, hydrothorax and edema of the extremities; extreme fatty infiltration of the liver; atrophy of the thyroid gland with focal adenomatous hyperplasia; atrophy of the uterus and mammary glands; minimal ovarian fibrosis with sparse small follicular cysts and with persistent primordial follicles (without ripening stages); marked generalized osteoporosis with multiple healing rib fractures and collapsed vertebral bodies; hypoplastic bone marrow and lymphoid tissue.

A 6-day urine collection, probably incomplete, was secured in 1936 during amenorrhea, when the urea clearance was normal.

S. J. (Referred by Drs. S. C. Freed and Samuel Soskin) (University of Chicago Clinics number 156840), age 13. The patient had hypertrichosis of the face, abdomen and extremities. The breasts were flat, and she had not as yet menstruated. Pelvic examination showed a questionably enlarged clitoris. Blood pressure was normal and physical examination was otherwise negative. Eight months after the urine collection the pelvis was explored by Dr. Karl Meyer.at Cook County Hospital who found large cystic ovaries, and no other abnormality.

A complete 7-day urine collection was secured in February 1935.

R. G. (Referred by Dr. A. K. Koff) (University of Chicago Clinics number 120522), age 32. The patient had hypertrichosis of the face, abdomen and extremities. She was somewhat heavy and her menses were irregular, occurring as infrequently as eight months apart, but she had given birth to two normal children. Physical examination showed nothing unusual. Pelvic examination showed bilaterally enlarged cystic ovaries.

A complete 7-day urine collection was secured immediately after the close of a menstrual period in October 1935.

P. R. (Referred by Dr. W. O. Thompson), age 31 . Patient was moderately obese, her plethoric face was covered with a downy growth of hair averaging $3 \mathrm{~mm}$. in length. An excess of hair was also present elsewhere, save for the scalp and axilla, where the amounts were scant. Except for one day's flow ten months previously, she had not menstruated for three years. The labia minora were small, the cervix long and conical, the uterus normal. The skin of the entire body was covered with irregular pink macules with purple striae over the iliac areas and buttocks. Her blood pressure ranged from 182 to $200 / 126$ to 150 . Her heart was enlarged, and edema of the feet and spontaneous ecchymoses had been present for six months. The thyroid gland was diffusely enlarged, a tremor of the fingers present; her basal metabolic rate was +18 . The urine contained 100 grams of sugar in 24 hours on a diet yielding 200 grams of glucose; her fasting blood-glucose was $170 \mathrm{mgm}$. per 100 cc., but, curiously, insulin seemed to aggravate her condition. X-rays of the sella turcica showed doubtful erosion. Pyelograms were negative.

She died with thrombotic occlusion of the left external iliac and femoral arteries associated with the heart failure. Necropsy showed cortical adenomata of the right adrenal gland with extensive necrosis and marked atrophy of the cortex of the left adrenal gland; myocardial hypertrophy and degeneration, the thrombotic processes with the resulting gangrene of the left leg, osteoporosis, and "parenchymatous degeneration" of the liver and kidneys. The pituitary was normal macroscopically and microscopically.

We have assayed a complete 3-day urine collection. It was secured during amenorrhea in May 1935.

G. C. (Referred by Dr. Raphael Kurzrok, Case number 3), age 16. (Reported in detail by Dr. Kurzrok (26).) Menses began at 13 and after two periods, stopped. Excessive hair appeared on her chest, arms, body, legs and face, the last requiring daily shaving - and her voice deepened. Her clitoris was found to be nearly two inches long. Her blood pressure was $138 / 76$, and an exhaustive laboratory examination was negative save for the beautiful demonstration by $x$-ray of a mass above the left kidney after the injection of air into the perirenal tissue. Her urine contained no follicle-stimulating hormone and 8 rat units of estrogenic substance. A complete urine collection for eight days was made and the mass then removed. The tumor on section proved to be a carcinoma of the adrenal cortex. Recovery was excellent, and in a month her menses returned, her voice became higher pitched, and her hair began coming off in the bath.

K. P. (Referred by Dr. Raphael Kurzrok, case number 4, reported in detail by Dr. Kurzrok), age 36. The patient had suffered from amenorrhea for six years, and from hypertrichosis of the body and face for three years. Her clitoris was very large. X-ray films, after perirenal air injection, showed a mass above the right kidney which was removed at operation. The patient died in postoperative collapse. Autopsy was refused. On section the tumor mass proved to be a carcinoma of the suprarenal cortex. Urine was collected for assay for male hormone for four days before the operation.

G. N. (Referred by Drs. Russell Wilder and George Crisler). The patient was obese and had a hypertrichosis of whisker distribution on the face. There were several dark bluish striae on the abdomen and upper thighs. Her menses had been grossly irregular with frequent amenorrhea. She complained of severe headaches and had been in a mental hospital several months of the previous year. Her systolic blood pressure ranged from 140 to 110 . Her glucose tolerance gave a diabetic type of curve but otherwise laboratory studies including visual fields and $x$-rays of the sella turcica were negative. On abdominal exploration, Dr. Waltman Walters found normal adrenals and ovaries and an atrophic uterus.

A 4-day urine collection was secured during amenorrhea in the spring of 1936 . 
TABLE III

The excretion of sex hormones in virilism

\begin{tabular}{|c|c|c|c|c|c|c|c|c|c|c|c|c|}
\hline \multirow{2}{*}{ Patient* } & \multirow{2}{*}{ Age } & \multirow{2}{*}{$\begin{array}{c}\text { Opera- } \\
\text { tion }\end{array}$} & \multirow{2}{*}{ Adrenals } & \multirow{2}{*}{ Ovaries } & \multirow{2}{*}{ Menses } & \multirow{2}{*}{$\begin{array}{c}\text { Duration } \\
\text { of } \\
\text { collection }\end{array}$} & \multirow{2}{*}{$\begin{array}{l}\text { Dura- } \\
\text { tion of } \\
\text { boiling }\end{array}$} & \multirow{2}{*}{$\begin{array}{l}\text { Num- } \\
\text { ber of } \\
\text { capons }\end{array}$} & \multicolumn{2}{|c|}{$\begin{array}{l}\text { International } \\
\text { androgen units } \\
\text { per day }\end{array}$} & \multirow{2}{*}{$\begin{array}{l}\text { Theelin } \\
\text { per day }\end{array}$} & \multirow{2}{*}{$\begin{array}{l}\text { Ratio } \\
\text { andro- } \\
\text { gens to } \\
\text { gamma } \\
\text { theelin }\end{array}$} \\
\hline & & & & & & & & & $\begin{array}{l}15 \\
\text { minutes }\end{array}$ & $\stackrel{2}{\text { hours }}$ & & \\
\hline R. Y.c... & $\begin{array}{c}\text { years } \\
18\end{array}$ & + & & $\begin{array}{c}\text { Enlarged } \\
\text { cystic }\end{array}$ & 0 & 7 days & $\begin{array}{c}\text { minutes } \\
120\end{array}$ & 7 & & 30 & $\begin{array}{l}\gamma \\
4\end{array}$ & 7.5 \\
\hline $\begin{array}{l}\text { M. N..... } \\
\text { E. H..... }\end{array}$ & $\begin{array}{l}21 \\
29\end{array}$ & + & Normal & Normal & $\begin{array}{l}\text { Regular } \\
\text { Slightly }\end{array}$ & $\begin{array}{l}7 \text { days } \\
3 \text { days }\end{array}$ & $\begin{array}{l}120 \\
120\end{array}$ & $\begin{array}{l}4 \\
7\end{array}$ & & $\begin{array}{l}16 \\
22\end{array}$ & $\begin{array}{r}6 \\
12\end{array}$ & $\begin{array}{l}2.7 \\
1.8\end{array}$ \\
\hline M. A..... & 23 & + & Normal & $\begin{array}{c}\text { Enlarged } \\
\text { sclerotic }\end{array}$ & Menor- & 3 days & 120 & 7 & & 24 & 18 & 1.3 \\
\hline A. D.... & 32 & + & Normal & Enlarged & Amenor- & 6 days & 15 & 7 & 8 & $5 \dagger$ & 10 & 0.2 \\
\hline $\begin{array}{l}\text { W. K...... } \\
\mathbf{E} . \mathbf{S} . \ldots .\end{array}$ & $\begin{array}{l}21 \\
25\end{array}$ & $\begin{array}{l}0 \\
+\end{array}$ & Normal & Enlarged & $\begin{array}{l}\text { Irregular } \\
\text { Amenor- }\end{array}$ & $\begin{array}{l}6 \frac{1}{2} \text { days } \\
10 \text { days }\end{array}$ & $\begin{array}{l}120 \\
120\end{array}$ & $\begin{array}{l}7 \\
4\end{array}$ & & $\begin{array}{l}44 \\
23\end{array}$ & $\begin{array}{l}17 \\
19\end{array}$ & $\begin{array}{l}2.6 \\
1.2\end{array}$ \\
\hline G. F..... & 17 & + & Normal & $\begin{array}{c}\text { Enlarged } \\
\text { cystic }\end{array}$ & $\begin{array}{l}\text { Irregular } \\
\text { to regular }\end{array}$ & 5 liters & 120 & 4 & & 34 per liter & 11 per liter & 3.0 \\
\hline C. $\mathrm{F}^{h} \ldots$ & 31 & Necropsy & Adenoma & $\begin{array}{l}\text { No ripe } \\
\text { follicles }\end{array}$ & Amenor- & 6 days & 15 & 7 & 14 per liter & 8 per liter $\dagger$ & 10 per liter & 0.8 \\
\hline S. J... & 13 & + & Normal & Enlarged & & 7 days & 120 & 4 & & 16 & 10 & 1.6 \\
\hline R. G..... & 32 & 0 & & $\begin{array}{c}\text { Enlarged } \\
\text { cystic } \\
\text { (Delvic) }\end{array}$ & Irregular & 7 days & 120 & & & & 16 & \\
\hline P. $\mathrm{R}^{\boldsymbol{h}, \boldsymbol{s}}$. & 31 & Necropsy & Adenoma & Normal & Amenor- & 3 days & 120 & 7 & & 0 & 4 & $0.25-$ \\
\hline G. C.c.... & 16 & + & $\begin{array}{l}\text { Car- } \\
\text { cinoma }\end{array}$ & & $\begin{array}{l}\text { Amenor- } \\
\text { rhea }\end{array}$ & & 120 & 7 & & 480 & 8 & 60.0 \\
\hline K. P. . . . & 36 & + & $\begin{array}{l}\text { Car- } \\
\text { cinoma }\end{array}$ & & $\begin{array}{l}\text { Amenor- } \\
\text { rhea }\end{array}$ & 4 days & 120 & 7 & & 69 & & \\
\hline $\begin{array}{l}\text { G. N...... } \\
\text { M. C..... }\end{array}$ & 25 & + & Normal & Normal & $\begin{array}{l}\text { Irregular } \\
\text { Regular }\end{array}$ & $\begin{array}{l}4 \text { days } \\
3 \text { days } \\
2 \text { days }\end{array}$ & $\begin{array}{l}15 \\
60 \\
60\end{array}$ & $\begin{array}{l}7 \\
7 \\
7\end{array}$ & $\begin{array}{r}74 \\
92 \dagger \\
111 \dagger\end{array}$ & $\begin{array}{l}44 \dagger \\
55 \dagger \\
64 \dagger\end{array}$ & $\begin{array}{l}14 \\
11 \\
<5\end{array}$ & $\begin{array}{r}3.2 \\
5.0 \\
12.8\end{array}$ \\
\hline \multicolumn{6}{|c|}{ Average (15 patients (except G. C.) ) $\ldots \ldots \ldots \ldots \ldots \ldots \ldots$} & 3 to 10 days & $\begin{array}{r}15 \text { to } \\
120\end{array}$ & 4 to 7 & & 28 & 11 & 2.6 \\
\hline \multicolumn{6}{|c|}{ Average (4 normals).. } & 6 weeks & $\begin{array}{c}15 \text { to } \\
120\end{array}$ & 7 & $47+$ & 28 & 25 & 1.1 \\
\hline
\end{tabular}

${ }^{*} \mathrm{~h}=$ hypertension; $\mathrm{c}=$ hypertrophied clitoris; $\mathrm{s}=$ purple abdominal striae.

† Calculated on the assumption that the 2-hour hydrolysis gives values 60 per cent of those secured by the 15minute hydrolysis and that the 1 -hour hydrolysis gives values 76 per cent of those at 15 minutes. The absolute values for Patient M. C. at the 1-hour hydrolysis are 70 and 84 units. The average ratios given are for the 2-hour hydrolysis.

M. C. (Referred by Dr. Russell Wilder), age 25. Save for the marked hypertrichosis of the face, abdomen and extremities, the patient presented no gross physical abnormality. Her menses, for a while appearing every 15 days, later became of normal periodicity. Pelvic examination was normal and extensive laboratory investigations including an intravenous pyelogram were negative. One of several Ascheim-Zondek tests was faintly positive, and there was on one occasion about 8.5 rat units per liter of estrogenic substances in the urine.

A 3-day and a 2-day urine collection were secured in the spring of 1936.

It will be recalled that in the three normal females studied extensively by seven capon assays, the urine being boiled for two hours, we found from 13 to 46 international androgen units in the 24 hour specimen with an average for each of about 26. Samplings of other normal women and the examination of pooled specimens are in agreement with these values. If we allow for the 40 per cent destruction when compared with the 15 minute hydrolysis, the average becomes 43 and the range 28 to 77 . In one normal woman, studied directly by the 15 minute hydrolysis, from 42 to 85 international units were passed, giving an average of 56 . Of the fifteen women with virilism studied for male hormone, twelve are within or below this normal range (Table III). Two (K. P., M. C.) are some 25 per cent higher than any normal yet studied. One patient (G. C.), a patient of Dr. Raphael Kurzrok, reported in detail by the Columbia group (26), showed the considerable sum of 480 international androgen units per day (two-hour hydrolysis). She had a proven carcinoma of the adrenal cortex. Furthermore, examination of this urine in the Department of Chemistry by Dr. T. F. Hogness and associates revealed an absorption spectrum unlike that of androsterone and like that of testosterone, 
androstene-dione and the adrenal cortical derivative supplied us by Kendall (discussed by the Rochester group (29)). Curiously, we were able to extract no male hormone from the tumor itself.

In the sixteen specimens examined for estrogenic material, no unusually large amount was found, indeed the average normal value was never reached. This may be correlated with the frequent amenorrhea and grossly pathological ovaries often found at operation.

It is difficult to bring regularity and simplicity into this data. A gross excess of masculinizing material is apparently excreted on occasion, in our experience in an instance of adrenal carcinoma. In other patients with virilism there is either no excess or very little. It is thus impossible, at the present time, to support the simple and attractive hypothesis that virilism is due to a hypersecretion of a recognized comb-growth stimulating hormone. The occasional striking positive finding, however, precludes the dismissal of this conception until studies have been made over the long periods during which this syndrome develops. Brief samplings are unfortunately inadequate, especially as the changes of virilism are structural and tend to remain at least for a while after the stimulus evoking them has subsided. Simpson, de Fremery and Macbeth (27) have apparently been more fortunate in their material as they secured a far higher proportion of positive findings. It is well in considering this problem to recall that Frank (25), in studying the urine of patients with adrenal cortical carcinoma, found large amounts of estrogenic material despite the obvious masculinization of the patients. This, too, is irregular, as Slot (Dingemanse) and Kurzrok found normal values. Frank's experience constitutes a curious obverse of the stallion (Zondek (11)) who, with unimpeachable masculinity, excretes much more estrogenic material than the mare.

We have, on occasion, wondered whether the ratio of male to female urinary constituents might not prove a better clue than the gross amounts, as in general normal men excrete more male hormone relative to female than do women. Sometimes this ratio is greatly displaced in the masculine direction (Patients R. Y., G. N. and M. C.), and it is rarely under 1.0 as is frequently true in the normal woman. This point, however, also awaits further work, especially with reference to the changes accompanying amenorrhea.

The adrenal cortex, of course, is suspected on clinical grounds as a source of the augmented excretion of male sex hormones when this occurs. Recent biochemical work has an interesting bearing on this possibility. Reichstein (30) has separated six crystalline substances from suprarenal cortical tissue. One of these, an unsaturated diketone, of the formula $\mathrm{C}_{18} \mathrm{H}_{24} \mathrm{O}_{3}( \pm \mathrm{C} \pm 2 \mathrm{H})$, he reported as one-fifth as active as androsterone $\mathrm{m}$ comb-growth stimulating activity. Inasmuch as this observation, as well as the composition and absorption spectrum of the substance, suggest a relation to the ring structure of cholestenone and testosterone, he called the substance adrenosterone. Kendall, Mason and Meyers (29) also obtained a diketone of the formula $\mathrm{C}_{19} \mathrm{H}_{24} \mathrm{O}_{3}$ by chromic acid oxidation of their compound $\mathrm{E}$ (Wintersteiner's and Pfiffner's compound F). The diketone, when examined spectrographically by Professor T. F. Hogness and his associates in the Department of Chemistry, gave absorption bands like those of cholestenone, testosterone and androstenedione, but unlike androsterone. When tested on the capon, we found it to be one-sixth to one-fourth as potent as androsterone. An oxidation product, $\mathrm{C}_{19} \mathrm{H}_{20} \mathrm{O}_{3}$, prepared by Drs. Oskar Wintersteiner and J. J. Pfiffner from suprarenal cortex and submitted to us for male hormone assay, also gave the same order of activity. The spectrographic findings are especially interesting because they suggest that the androgenic activity and absorption spectrum of the androgenic fraction obtained from the urine of Kurzrok's patient Number 3 are not due to androsterone and dehydroandrosterone, but to an androgenic substance of suprarenal origin which may be closely related to Reichstein's adrenosterone. Its production may be due to a pathological process or perverted metabolism as a result of which such a substance may be formed or be allowed to accumulate in the blood stream to abnormal levels.

Acknowledgments: This work could not have been conducted without the cooperation of many interested physicians, each of them aware of the possible significance of assays for these hormones. For the collection 
of urine we are greatly indebted to Dr. W. O. Thompson, Cook County Hospital, Chicago; Dr. Raphael Kurzrok, Presbyterian Hospital, New York; Dr. A. A. Weinstein, Vanderbilt University Hospital, Nashville; Dr. Thomas Myers, St. Paul, Minnesota; Drs. Russell M. Wilder and George Crisler of the Mayo Clinic; and the late Dr. James Austin of Columbia, South Carolina. For the placing of their clinical material at our disposal, we are indebted to Dr. S. C. Freed and Dr. Samuel Soskin of Michael Reese Hospital, Dr. I. Becker of the University of Illinois, Dr. M. Kolovros of Gary, Indiana, and Drs. Henry L. Schmitz, W. M. Brunet, W. S. Timblin of Chicago, and Drs. Carl Moore, Percival Bailey, Paul Bucy, C. B. Huggins, Louis Leiter, Edmund Andrews, A. K. Koff, Henry Ricketts and Henry Jacobs of our own staff.

\section{SUMMARY}

1. Two castrated men excreted traces only of androgenic (comb-growth promoting) and estrogenic substances.

2. Seven eunuchoids excreted on the average a third of the normal amount of androgens, overlapping the normal range on occasion. The output of estrogens was also low. One patient with hypopituitarism excreted small amounts only of both substances.

3. Of four patients with gynecomastia none excreted an excess of estrogenic material. The androgens varied from none at all to a normal amount.

4. Sixteen patients with virilism excreted as a rule normal amounts of androgenic material. A moderate excess of androgens is occasionally found, and the great excess of 480 international units per day was found in one case of carcinoma of the adrenal cortex. The urine of this patient possessed the spectrographic properties of testosterone, androstenedione or cholestenone rather than of androsterone. It was similar in this respect to certain compounds derived from the adrenal cortex. We have had no instances as yet of increased excretion of estrogens in virilism.

\section{BIBLIOGRAPHY}

1. Gallagher, T. F., Koch, F. C., and Dorfman, R. I., Procedure for quantitative extraction of sex hormones from urine. Proc. Soc. Exper. Biol. and Med., 1935, 33, 440.

2. Gallagher, T. F., Peterson, D. H., Dorfman, R. I., Kenyon, A. T., and Koch, F. C., The daily urinary excretion of estrogenic and androgenic substances by normal men and women. J. Clin. Invest., 1937, 16, 695.
3. Gallagher, T. F., and Koch, F. C., The quantitative assay for the testicular hormone by the combgrowth reaction. Second communication. J. Pharmacol. and Exper Therap., 1935, 55, 97.

4. D'Amour, F. E., and Gustavson, R. G, A critical study of the assay of female sex hormone preparations. J. Pharmacol. and Exper. Therap., 1930, 40, 473.

5. Deanesly, R., and Parkes, A. S., Oestrogenic action of compounds of the androsterone-testosterone series. Brit. M. J., 1936, 1, 257.

6. McCullagh, E. P., and Renshaw, J. F., The effects of castration in the adult male. J. A. M. A., 1934, $103,1140$.

7. Eng, Hans, Uber das Follikulin im Kastrierten Organismus. Klin. Wchnschr., 1936, 15, 349.

8. Frank, R. T., Goldberger, M. A., and Salmon, U. J., Estrogenic substances in the blood and urine after castration and the menopause. Proc. Soc. Exper. Biol. and Med., 1936, 33, 615.

9. Altmann, F., Uber Eunuchoidismus. Virchows Arch. f. path. Anat., 1930, 276, 455.

10. Hamburger, C., Studies on gonadotropic hormones from the hypophysis and chorionic tissue with special reference to their differences. Acta path. et microbiol. Scandinav., 1933, Suppl. 17, p. 35.

11. Zondek, B., Hormone des Ovariums und des Hypophysenvorderlappens. Zweite Aufl. J. Springer, Wien, 1935, p. 248.

12. Lewis, D., and Geschickter, C. F., Gynecomastia, virginal hypertrophy and fibroadenomas of the breast. Ann. Surg., 1934, 100, 779.

13. Nelson, W. O., Endocrine control of the mammary gland. Physiol. Rev., 1936, 16, 488.

14. Selye, Hans, McEuen, C. S., and Collip, J. B., Effect of testosterone on the mammary gland. Proc. Soc. Exper. Biol. and Med., 1936, 34, 201.

15. Nelson, W. O., and Gallagher, T. F., Some effects of androgenic substances in the rat. Science, 1936, 84, 230.

16. Hammett, F. S., Gynecomastia. Endocrinology, 1920, 4, 205.

17. Heidrich, L., Fels, E., and Mathias, E., Testikuläres Chorionepitheliom mit gynäkomastie und mit einigen Schwangerschaftserscheinungen. Gleichzeitig ein Beitrag zur Pathologie der hormonalaktiven Gewächse. Beitr. z. klin. Chir., 1930, 150, 349.

18. Jung, F. T., and Shafton, A. L., The mammary gland in the normal adolescent male. Proc. Soc. Exper. Biol. and Med., 1935, 33, 455.

19. Starr, P., Gynecomastia during hyperthyroidism. Report of two cases. J. A. M. A., 1935, 104, 1988.

20. Cushing, H., "Dyspituitarism": twenty years later. With special consideration of the pituitary adenomas. Arch. Int. Med., 1933, 51, 487.

21. Crooke, A. C., A change in the basophil cells of the pituitary gland common to conditions which exhibit the syndrome attributed to basophil adenoma. J. Path. and Bact., 1935, 41, 339. 
22. Broster, L. R., and Vines, H. W. C., The adrenal cortex: a surgical and pathological study. H. K. Lewis \& Co., London, 1933.

23. Saphir, William, and Parker, M. L., Adrenal virilism. J. A. M. A., 1936, 107, 1286.

24. Bühler, F., Sexualhormonbefunde im Harn von Männern verschiedenen Alters. Ztschr. f. d. ges. exper. Med., 1933, 86, 650.

25. Frank, R. T., A suggested test for functional cortical adrenal tumor. Proc. Soc. Exper. Biol. and Med., 1934, 31, 1204.

26. Cahill, G. F., Loeb, R. F., Kurzrok, R., Stout, A. P., and Smith, F. M., Adrenal cortical tumors. Surg., Gynec., and Obst., 1936, 62, 287.

27. Simpson, S. L., de Fremery, P., and Macbeth, A., The presence of an excess of male (comb-growth and prostate-stimulating) hormone in virilism and pseudo-hermaphroditism. Endocrinology, 1936, 20, 363.
28. Slot, W. J. B., The relation of sex hormones in a case of virilism by hypernephroma. Acta med. Scandinav., 1936, 89, 371.

29. Kendall, E. C., Mason, H. L., and Meyers, C. S., Concerning the chemical nature of the hormone of the adrenal cortex. Proc. Staff Meet. Mayo Clin., 1936, 11, 351.

30. Reichstein, T., Adrenosterone. Uber die Bestandteile der Nebennierenrinde. II. Helv. Chim. Acta., 1936, 19, 223.

31. Tandler, J., and Grosz., S., Uber den Einfluss der Kastration auf den Organismus. Arch. f. Entwcklngsmechn. d. Organ., 1910, 29, 290.

32. Dingemanse, E., Borchardt, H., and Laqueur, E., Capon comb growth-promoting substances (" male hormones") in human urine of males and females of varying age. Biochem. J., 1937, 36, 500. 